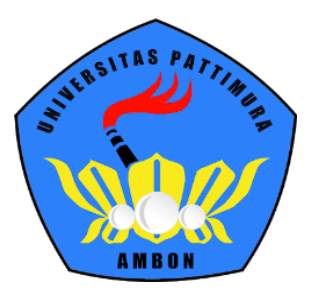

BIOEDUPAT:

Pattimura Journal of Blology and Learning

http://ojs3.unpattl.ac.Id/index.php/bloedupat

e-ISSN 2775-4472

Research Article

\title{
The effect of use environmental based practicum methods on students' cognitive, interest, and effective learning outcomes at public school 11 Southeast Maluku and Anugerah Christian High School
}

\author{
Fanny Tuakora ${ }^{1}$, Merry Pattipeilohy ${ }^{1}$, Johanis Fritzgal Rehena ${ }^{1}$ \\ 1 Department of Biology Education, Pattimura University, Street. Ir. M. Putuhena, Ambon 97233, Indonesia
}

Received: June 2, 2021

Revised: June 05, 2021

Accepted: October 18, 2021

\begin{abstract}
The function of national education is to shape the character and civilization of the nation, while developing the potential of students to be faithful, devoted, have noble character, be capable, creative, independent, democratic, and responsible. This study was to determine whether there is an effect of using environmental-based practicum methods on the identification of the types of protists on cognitive learning outcomes, interest in learning, and students' affective values. The method used in this research is quasi-experimental. (1) The effect of cognitive learning outcomes, the value of $t$ count is greater than $t$ table (27.793 $>2,000)$, $(21.145>2.001)$. (2) The effect of interest in learning, the value of $t$ count is greater than the value of $t$ table $(42.268>$ $2,000),(36.030>2.001)$. (3) The effect of students' affective scores: the t-count value is greater than the t-table value $(20,044>$ $2,000),(30,734>2,001)$. There is a significant effect of using environmental-based practicum methods on cognitive learning outcomes, interest in learning, and affective values
\end{abstract}

Keywords: Method, practicum, environment.

To cite this article:

Tuakora, F., Pattipeilohy, M., \& Rehena, J.F. 2021. The effect of use environmental based practicum methods on students' cognitive, interest, and effective learning outcomes at public school 11 Southeast Maluku and Anugerah Christian High School. Bioedupat: Pattimura Journal of Biology and Learning, Vol 1(2), 79-83. DOl: https://doi.org/10.30598/bioedupat.v1.i2.pp79-83

\section{INTRODUCTION}

Education is a planned effort with full awareness in order to realize the learning process with the aim that students can actively develop their potential (Suci, 2015). The function of national education is to shape the character and civilization of the nation while developing the potential of students to be faithful, devoted, noble, capable, creative, independent, democratic, responsible is the goal of national education (Nisa, 2017). Talking about education, it cannot be separated from what is called learning. Learning is a process used in an educational institution to distribute and share knowledge (Nisa, 2017). According to Sanjaya (2005), learning is a process of interaction between humans and humans or humans and the environment, so that the goals that have been set will be achieved. So that the material taught to students is easy to understand, in the teaching process the teacher must 
pay attention to learning methods, one of which is the environment-based practicum method. Environmental-based learning is a learning that uses learning objects as real experiences Juairiah, et al (2014).

Practicum is a subsystem of learning that provides opportunities for students to get real experience in increasing students' understanding of theory. According to Suharso (2011), practicum is teaching that aims to give students the opportunity to test and implement what is learned in theory. An example of material that requires the pacticum method is the identification of the types of protists. The objectives/benefits of the practicum method include: (1) practicum activities can train skills, (2) practicum activities provide opportunities for students to apply and integrate their knowledge and skills in practice, (3) practicum activities prove something scientifically/do scientific inquiry, (4) appreciate the knowledge and skills of inquiry (Susanti, 2013). There are four reasons regarding the importance of practicum activities, including: (1) Practicum generates learning motivation, (2) Practicum generates basic skills in conducting experiments, (3) Practicum becomes a vehicle for learning scientific approaches, (4) Practicum supports subject matter (Rustaman, 2003).

The results of observations at the State High School 11 Southeast Maluku and Anugerah Vocational High School obtained: (1) Biology learning carried out by teachers is only limited to the transfer of information, students are not given the opportunity to think scientifically, (2) Emphasis on delivering material from textbooks that exists so that students only memorize, (3) teacher-centered teaching methods cause students to be passive, less trained in science/scientific, (4) students rarely do practicum due to limited tools and materials in the laboratory, (5) lack of creativity of eye teachers lessons to overcome the limitations of infrastructure by utilizing existing environmental resources (natural resources) as learning media or practicum materials. Based on the explanation, the researcher felt the need to use an environment-based practicum method in the identification of the types of protists that were expected to improve students' cognitive, interest, and affective learning outcomes.

\section{METHODS}

This study uses a quasi-experimental research method by giving treatment to the experimental group while the control group as a comparison. The population is all students of Southeast Maluku State 11 Senior High School and Anugerah Vocational High School, totaling 342 students and the sample is all class X students, totaling 122 students. The data collection techniques are as follows: (a) Observation, (b) Research design, (c) Literature study, (d) Making research instruments, (e) Grouping samples, (f) Carrying out evaluations, (g) Implementing practicum at coastal locations , forest and home environment, (h) Giving posttest, (i) Filling out questionnaires, (j) processing data, (k) Summarizing the results of the study.

\section{RESULTS AND DISCUSSION}

This study aims to see whether there is an effect of using environmental-based practicum methods on students' cognitive, interest and affective learning outcomes. At the data analysis stage, several stages were carried out, namely: analysis of students' post test scores, analysis of questionnaire scores and analysis of observation sheets of students' affective values.

Table 1. The results of data analysis on the effect of environmental-based practicum methods on cognitive learning outcomes of State High School 11 Southeast Maluku students

\begin{tabular}{|c|c|c|c|c|c|c|c|c|c|}
\hline \multicolumn{10}{|c|}{ Independent sample test } \\
\hline & \multicolumn{2}{|c|}{$\begin{array}{l}\text { Leven's test } \\
\text { for equallity } \\
\text { variance }\end{array}$} & \multicolumn{7}{|c|}{ t-test for equality of means } \\
\hline & \multirow[t]{2}{*}{$F$} & \multirow[t]{2}{*}{ sig } & \multirow[t]{2}{*}{$\mathrm{T}$} & \multirow[t]{2}{*}{ df } & \multirow[t]{2}{*}{$\begin{array}{l}\text { Sig-(2- } \\
\text { tailed) }\end{array}$} & \multirow[t]{2}{*}{$\begin{array}{l}\text { Mean } \\
\text { difference }\end{array}$} & \multirow[t]{2}{*}{$\begin{array}{l}\text { Std error } \\
\text { difference }\end{array}$} & \multicolumn{2}{|c|}{$\begin{array}{l}95 \% \text { confidence } \\
\text { interval difference }\end{array}$} \\
\hline & & & & & & & & lower & Upper \\
\hline $\begin{array}{l}\text { Equal variaces } \\
\text { assumed } \\
\text { Aqual variances not }\end{array}$ & 0.169 & 0.683 & -27.793 & 60 & 0.00 & -32.670 & 1.175 & -35.221 & -30.31 \\
\hline assumed & & & -27.894 & 59.87 & 0.00 & -32.670 & 1.171 & -35.013 & -30.32 \\
\hline
\end{tabular}


Based on the results in Table 1. the calculated t value is greater than the t table value $(27,793>2,000)$ and Sig. (2-tailed) $=0.000<0.05$, which means that there is a significant effect of using environmental-based practicum methods on cognitive learning outcomes.

Table 2. Results of data analysis on the effect of environmental-based practicum methods on cognitive learning outcomes of Anugerah Vocational High School students

Independent sample test

\begin{tabular}{|c|c|c|c|c|c|c|c|c|c|}
\hline & \multicolumn{2}{|c|}{$\begin{array}{l}\text { Leven's test } \\
\text { for equallity } \\
\text { variance }\end{array}$} & \multicolumn{7}{|c|}{ t-test for equality of means } \\
\hline & \multirow[t]{2}{*}{$\mathrm{F}$} & \multirow[t]{2}{*}{ sig } & \multirow[t]{2}{*}{$\mathrm{T}$} & \multirow[t]{2}{*}{$d f$} & \multirow[t]{2}{*}{$\begin{array}{l}\text { Sig-(2- } \\
\text { tailed) }\end{array}$} & \multirow[t]{2}{*}{$\begin{array}{l}\text { Mean } \\
\text { difference }\end{array}$} & \multirow[t]{2}{*}{$\begin{array}{l}\text { Std error } \\
\text { difference }\end{array}$} & \multicolumn{2}{|c|}{$\begin{array}{l}95 \% \text { confidence } \\
\text { interval difference }\end{array}$} \\
\hline & & & & & & & & lower & Upper \\
\hline $\begin{array}{l}\text { Equal variaces } \\
\text { assumed } \\
\text { Aqual variances not } \\
\text { assumed }\end{array}$ & 0.115 & 0.73 & -21.14 & 56.42 & 0.00 & -25.70 & 1.21 & -28.13 & -23.26 \\
\hline
\end{tabular}

Based on the results in Table 2. shows that the value of $t$ count is greater than the value of t table (21.145 > 2.001) and Sig. (2-tailed) $=0.000<0.05$, it means that there is a significant effect from the use of this method.

Table 3. The results of data analysis on the influence of environmental-based practicum methods on the learning interest of students at State High School 11 Southeast Maluku

\begin{tabular}{|c|c|c|c|c|c|c|c|c|c|}
\hline & \multicolumn{2}{|c|}{$\begin{array}{l}\text { Leven's test } \\
\text { for equallity } \\
\text { variance }\end{array}$} & \multicolumn{7}{|c|}{ t-test for equality of means } \\
\hline & \multirow[t]{2}{*}{$\mathrm{F}$} & \multirow[t]{2}{*}{ sig } & \multirow[t]{2}{*}{$\mathrm{T}$} & \multirow[t]{2}{*}{$d f$} & \multirow[t]{2}{*}{$\begin{array}{l}\text { Sig-(2- } \\
\text { tailed) }\end{array}$} & \multirow[t]{2}{*}{$\begin{array}{l}\text { Mean } \\
\text { difference }\end{array}$} & \multirow[t]{2}{*}{$\begin{array}{l}\text { Std error } \\
\text { difference }\end{array}$} & \multicolumn{2}{|c|}{$\begin{array}{l}95 \% \text { confidence } \\
\text { interval difference }\end{array}$} \\
\hline & & & & & & & & lower & Upper \\
\hline $\begin{array}{l}\text { Equal variaces } \\
\text { assumed } \\
\text { Aqual variances not } \\
\text { assumed }\end{array}$ & 1.94 & 0.94 & -42.26 & 59.78 & 0.00 & -37.14 & 0.87 & -38.90 & -35.39 \\
\hline
\end{tabular}

Based on the results in Table 4, the calculated $t$ value is greater than the $t$ table value $(42.268>2,000)$ and Sig. (2-tailed) $=0.000<0.05$, meaning that there is a significant effect from the use of this method.

Table 4. Results of data analysis on the effect of environmental-based practicum methods on the learning interest of Anugerah Vocational High School students

Independent sample test

\begin{tabular}{|c|c|c|c|c|c|c|c|c|}
\hline & \multicolumn{2}{|c|}{$\begin{array}{l}\text { Leven's test } \\
\text { for equallity } \\
\text { variance } \\
\end{array}$} & \multicolumn{6}{|c|}{ t-test for equality of means } \\
\hline & $\mathrm{F}$ & sig & $\mathrm{T}$ & $\mathrm{df}$ & $\begin{array}{l}\text { Sig-(2- } \\
\text { tailed) }\end{array}$ & $\begin{array}{l}\text { Mean } \\
\text { difference }\end{array}$ & $\begin{array}{l}\text { Std error } \\
\text { difference }\end{array}$ & $\begin{array}{l}95 \% \text { confidence } \\
\text { interval difference }\end{array}$ \\
\hline & & & & & & & & \begin{tabular}{|l|l|} 
lower & Upper \\
\end{tabular} \\
\hline
\end{tabular}




\begin{tabular}{|l|l|l|l|l|l|l|l|l|l|}
\hline $\begin{array}{l}\text { Equal variaces } \\
\text { assumed } \\
\begin{array}{l}\text { Aqual variances not } \\
\text { assumed }\end{array}\end{array}$ & 1.34 & 0.25 & -36.03 & 58 & 0.00 & -37.14 & 1.03 & -39.48 & -35.32 \\
\hline
\end{tabular}

Based on the results in Table 4. shows that the value of $t$ count is greater than the value of $t$ table $(36.030>$ 2.001) and Sig. (2-tailed) $=0.000<0.05$, it means that there is a significant influence from the use of this practicum method.

Table 5. Results of data analysis on the effect of environmental-based practicum methods on the affective values of State 11 Senior High School students Southeast Maluku

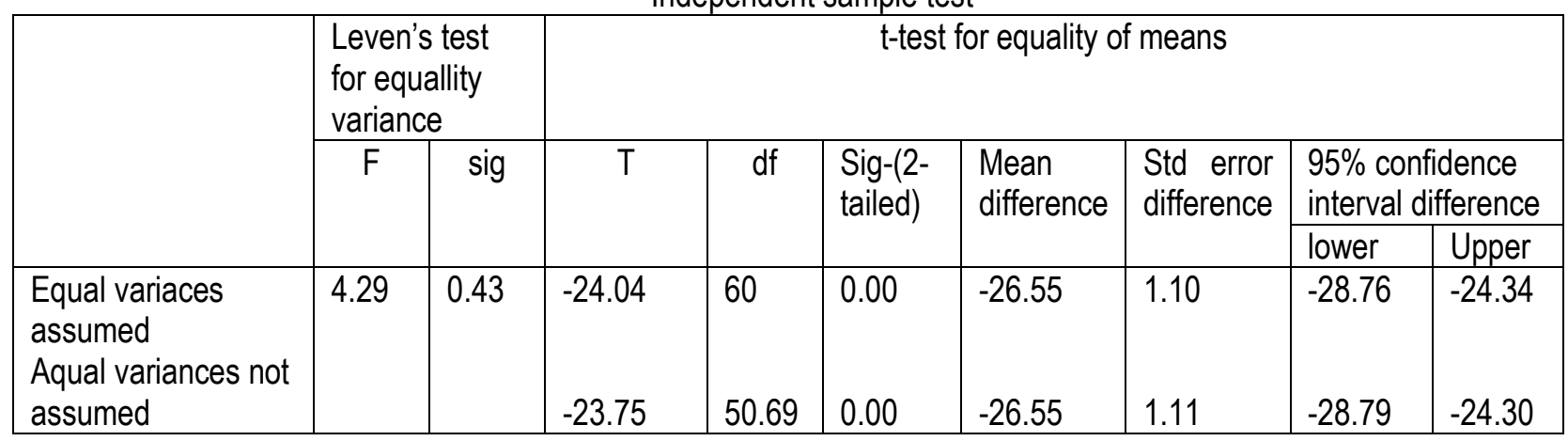

Based on the results in Table 5. shows that the value of $\mid t$ count is greater than the value of $t$ table $(20,044>$ 2,000 ) and Sig. (2-tailed) $=0.000<0.05$, meaning that there is a significant effect from the use of this method.

Table 6. Results of data analysis on the effect of environmental-based practicum methods on the affective values of Anugerah Vocational High School

\begin{tabular}{|c|c|c|c|c|c|c|c|c|c|}
\hline \multicolumn{10}{|c|}{ e } \\
\hline & \multicolumn{2}{|c|}{$\begin{array}{l}\text { Leven's test } \\
\text { for equallity } \\
\text { variance }\end{array}$} & \multicolumn{7}{|c|}{ t-test for equality of means } \\
\hline & \multirow[t]{2}{*}{$F$} & \multirow[t]{2}{*}{ sig } & \multirow[t]{2}{*}{$T$} & \multirow[t]{2}{*}{ Df } & \multirow[t]{2}{*}{$\begin{array}{l}\text { Sig-(2- } \\
\text { tailed) }\end{array}$} & \multirow[t]{2}{*}{$\begin{array}{l}\text { Mean } \\
\text { difference }\end{array}$} & \multirow[t]{2}{*}{$\begin{array}{l}\text { Std error } \\
\text { difference }\end{array}$} & \multicolumn{2}{|c|}{$\begin{array}{l}95 \% \text { confidence } \\
\text { interval difference }\end{array}$} \\
\hline & & & & & & & & lower & Upper \\
\hline $\begin{array}{l}\text { Equal variaces } \\
\text { assumed } \\
\text { Aqual variances not } \\
\text { assumed }\end{array}$ & 7.73 & 0.007 & -30.73 & 50.10 & 0.00 & -30.45 & 0.99 & -32.43 & -28.46 \\
\hline
\end{tabular}

Based on the results in Table 6. It shows that the t-count value is greater than the t-table value $(30,734>2.001)$ and Sig. (2-tailed) $=0.000<0.05$, meaning that there is a significant effect from the use of this method. This is in line with the opinion of Dedi Aryadi (2011), who said that student learning outcomes using environmental-based practicum methods were higher than those using the lecture method, especially on protist material. Ani Hastuti (2013), stated that learning practicum methods can improve learning outcomes and in line with previous research, researchers also found that learning practicum methods with materials in everyday life can improve student learning outcomes.

Based on the results of hypothesis testing, it shows that the use of environment-based practicum methods is very influential in increasing student interest in learning in this study. This increase in student interest in learning is also 
evidenced by the results of the questionnaire, namely that most students strongly agree to the application of the environment-based practicum method because it can provide opportunities for students themselves to be active in solving a problem in learning. According to Crow (2012), one of the factors that influence interest is that stimuli that come from the environment or scope that are in accordance with one's desires or needs will easily generate interest. The stimulus can be in the form of varied learning methods, for example, environmental-based practicum methods. Amelia (2011), said that practicum activities can improve scientific learning and improve students' affective domains. In addition, Mulyasa (2003), said that using practical learning can increase student activity which is an affective aspect. effectiveness of using environment-based practicum methods is that it results in a higher speed of student understanding in lessons, students become more creative and affective learning outcomes increase (Sugiono, 2007).

\section{CONCLUSION}

The conclusion that can be drawn is that there is a significant effect from the use of environmental-based practicum methods with the identification of the types of protists, on cognitive learning outcomes, interests and affective values students of State 11 High School Southeast Maluku and Anugerah Christian High School.

\section{REFERENCES}

Nisa. 2017. Discipline in early childhood. Pedagogy. Sidoarjo.

Holy. 2015. The Essence of Strategic Management. Zifatama Publisher. Sidoarjo.

Sanjaya. 2011. Classroom Action Research. Prenada Media Group. Jakarta.

Juariah. 2014. Environmental-based learning to improve student learning outcomes on the concept of Spermatophyta diversity. Journal of Educational Biology.

Hamida. 2015. The relationship between the quality of the physical home environment and the incidence of pulmonary tuberculosis. Sam Ratulangi university biomedicine. Manado.

Rustaman. 2003. Basic ability to work scientifically in Natural Sciences. Bandung.

Suharso. 2011. Big Indonesian Dictionary. CV. Widya works. Semarang.

Susanti. 2013. Effect of ethics and audit competence on audit quality.

Dedi Aryadi. 2011. The effect of using environmental-based practicum methods on student learning outcomes at Tanjungpura University. Pontianak.

Ani and Hastuti. 2013. Application of practicum-based learning to improve motivation and learning outcomes of biology subject matter of the Reproductive System. Sunan Kalijaga.Yogyakarta.

Crows. 2012. Human development and learning. New York.

Mulyasa. 2007. Education Unit Level Curriculum. PT Youth Rosdakarya. Bandung.

Sugiyono. 2007. Qualitative Quantitative Research Methods. Alphabet. Bandung.

Amelia. 2011. Analysis of Subsystem Linkages in Cocoa Agribusiness Subsystems in Padang Pariaman Regency. Andalas University. Padang. 